\title{
Hf isotopes from Palawan Continental Terrane, Philippines-clues to the evolution of sediment sources
}

\author{
Monika Walia ${ }^{1,2, *}$ and Ulrich Knittel ${ }^{2,3}$ \\ ${ }^{1}$ Department of the Earth and Environmental Sciences, National Chung Cheng University, Chiayi, Taiwan \\ ${ }^{2}$ Department of Geosciences, National Taiwan University, Taipei City, Taiwan \\ ${ }^{3}$ Department of Earth Sciences, RWTH Aachen University, Germany
}

\begin{abstract}
Article history:
Received 15 January 2017

Revised 6 February 2018

Accepted 23 February 2018

Keywords:

Central Philippines, Hf isotope composition, Detrital zircon, SE China

Citation:

Walia, M. and U. Knittel, 2018: Hf isotopes from Palawan Continental Terrane, Philippines-clues to the evolution of sediment sources. Terr. Atmos. Ocean. Sci., 29, 523-534, doi: 10.3319/TAO.2018.02.23.01
\end{abstract}

\begin{abstract}
The age spectra of detrital zircons in meta-sediments from Palawan Island, Mindoro Island, Tablas, and the Buruanga Peninsula of Panay Island in the Central Philippines provide evidence for the provenance of these zircons in the northern part of the Cathaysia Block, SE China. These islands form the western part of the Philippine archipelago and are part of the Palawan Continental Terrane (PCT), which is considered to be a rifted fragment of the continental margin of SE China which moved south from its original location as a consequence of the opening of the South China Sea (SCS). This rifted fragment contains records of the history of the continental margin of SE China. In this study, we present Hf isotopic compositions of previously dated zircon grains by $\mathrm{U}-\mathrm{Pb}$ dating technique, in meta-sediments from PCT. The results indicate that for several age groups, in particular those of 80 - 93, 245 - 270, and 400 - $465 \mathrm{Ma}, \varepsilon \mathrm{Hf}(\mathrm{T})$ of the zircons from the PCT is higher than in corresponding zircons from mainland SE China implying greater contributions from the mantle to the magmas from which these zircons crystallized. This suggests that most of the zircons found in the PCT were not transported over long distances from the interior of the SE Chinese cratons but are derived from regional sources, which are represented by the Camarong Gneiss and the rhyolite in Mindoro.
\end{abstract}

\section{INTRODUCTION}

The Palawan Continental Terrane (PCT), forming the western central part of the Philippine archipelago, originated at the margin of coastal SE China and drifted into its present position as a result of the opening of the South China Sea at about 32 - 16 Ma (e.g., Taylor and Hayes 1980). This concept was initially based largely on geophysical studies of the South China Sea (Taylor and Hayes 1980, 1983). Numerous authors also pointed out that sediments on Palawan and other islands comprising the PCT are unusually rich in quartz for which there are no or few source rocks in the Philippine archipelago (e.g., Gervasio 1967; Hamilton 1979; Holloway 1982). Detailed petrographic studies of (meta-) sediments in Palawan revealed their derivation from acidic plutonic and/or metamorphic rocks and acidic volcanics (Suzuki et al. 2000) which are abundant in SE China, but not known in the Philippine archipelago. For the north-western tip of the island of

\footnotetext{
* Corresponding author

E-mail:d93224007@ntu.edu.tw
}

Panay, the Buruanga Peninsular, Gabo et al. (2009) reached a similar conclusion, largely based on rock geochemistry.

Dating of detrital zircons extracted from sediments in Palawan, Tablas, Mindoro, and Panay has further established the link between the sedimentary rocks exposed in the PCT and potential sediment sources in SE China (Walia et al. 2012, 2013; Suggate et al. 2014; Knittel et al. 2017) as many zircons have Precambrian ages. While rocks of Precambrian age form the basement of SE China, rocks of Precambrian age are not known in the Philippine archipelago.

Analysis of the Hf isotopic composition of dated detrital zircons and comparison with data obtained for detrital zircons in SE China may elucidate the source areas in more detail and provide additional insights into the evolution of the source areas of the sedimentary rocks of the PCT.

\section{REGIONAL GEOLOGY AND SAMPLES}

The Philippine archipelago is located between the 
Philippine Sea in the east and the South China Sea to the west. It is considered to be composed of a complex arc system in the east, the Philippine Mobile Belt (PMB) and a continental fragment, the Palawan Continental Terrane (PCT) in the west (Fig. 1a). Along its western margin, the South China Sea is consumed along the Manila Trench and the Negros Trench, whereas the Philippine Sea plate is consumed along the eastern margin of the archipelago along the North Luzon Trough and the Philippine Trench (Fig. 1a).

The PCT consists of large parts of the islands of Palawan and Mindoro, the Romblon Island Group (including Tablas) and the Buruanga Peninsular of Panay (Fig. 1b). The exact boundaries of the PCT are still a matter of debate (e.g., Hamilton 1979; Yumul et al. 2005).

\subsection{Palawan}

The SW-NE trending island of Palawan is located at the south-eastern margin of the South China Sea and forms the north-western margin of the PCT. The northernmost part of the island is occupied by a melange unit comprising largely Permian to Triassic cherts (Hashimoto and Sato 1973; Wolfart et al. 1986; Faure and Ishida 1990) with some limestone of Devonian age (Kiessling and Flügel 2000). This melange is considered to be an accretionary complex of Jurassic age (e.g., Faure and Ishida 1990). South of this melange, clastic metasediments are exposed (Hashimoto and Sato 1973; Suzuki et al. 2000) that were initially considered to represent an old basement (e.g., Hashimoto and Sato 1973; Wolfart et al. 1986), but were recently found to be of Cretaceous age as detrital zircons contained therein have ages as young as
70 Ma (Walia et al. 2012; Suggate et al. 2014). Major age populations occur at $110-130 \mathrm{Ma}$ (112 out of 282 grains analyzed) and at $\sim 1.8 \mathrm{Ga}$. (63 zircon grains). This age pattern obtained from the zircons points to their origin in northern Cathaysia Block of South China (Wuyi Mountains; Walia et al. 2012; Suggate et al. 2014). Further to the south, the geology of Palawan is dominated by ophiolites overthrusting clastic sequences, largely of Eocene age (e.g., Aurelio et al. 2014; Suggate et al. 2014).

Our samples from Palawan are those for which U-Pb zircon ages were reported by Walia et al. (2012). These were collected from the low-grade, clastic meta-sediments exposed south of the northern melange unit.

\subsection{Mindoro}

Mindoro forms the northern tip of the PCT. The island is usually subdivided into four major blocks, the southwestern and north-eastern blocks, separated by the Amnay Ophiolite terrane, and a sedimentary basin in the east (e.g., Canto et al. 2012). The north-eastern block is largely underlain by the Mindoro Metamorphics, a complex of various schists, largely of Late Carboniferous to Early Permian age. The complex was intruded by the Camarong Gneiss in the Late Permian (Knittel and Daniels 1987; Knittel et al. 2010). Detrital zircons separated from recent river sediments draining the metamorphic complex suggest that the igneous episode represented by the Camarong Gneiss lasted from about 240 - $270 \mathrm{Ma}$. The igneous activity is considered to have been related to an active margin extending from Hainan ( $\mathrm{Li}$ et al. 2006) to south-eastern China (Li et al. 2012a). In the (a)

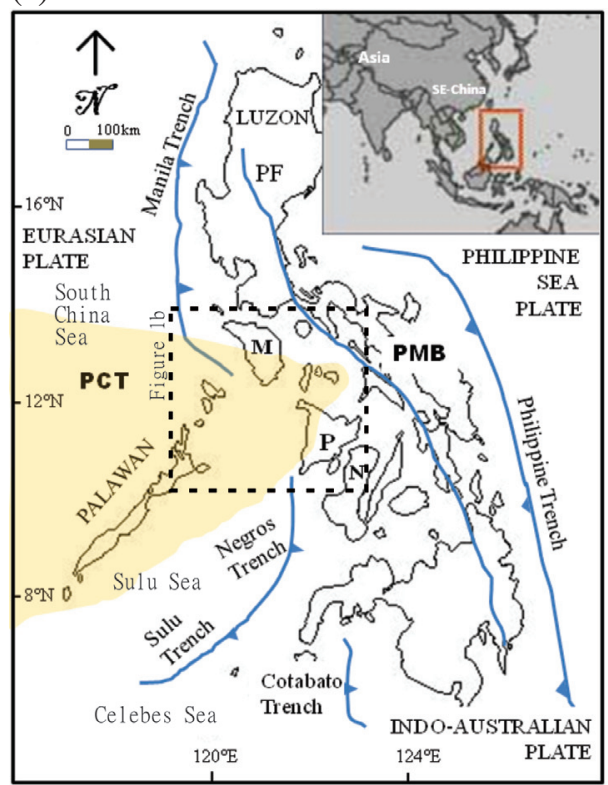

(b)

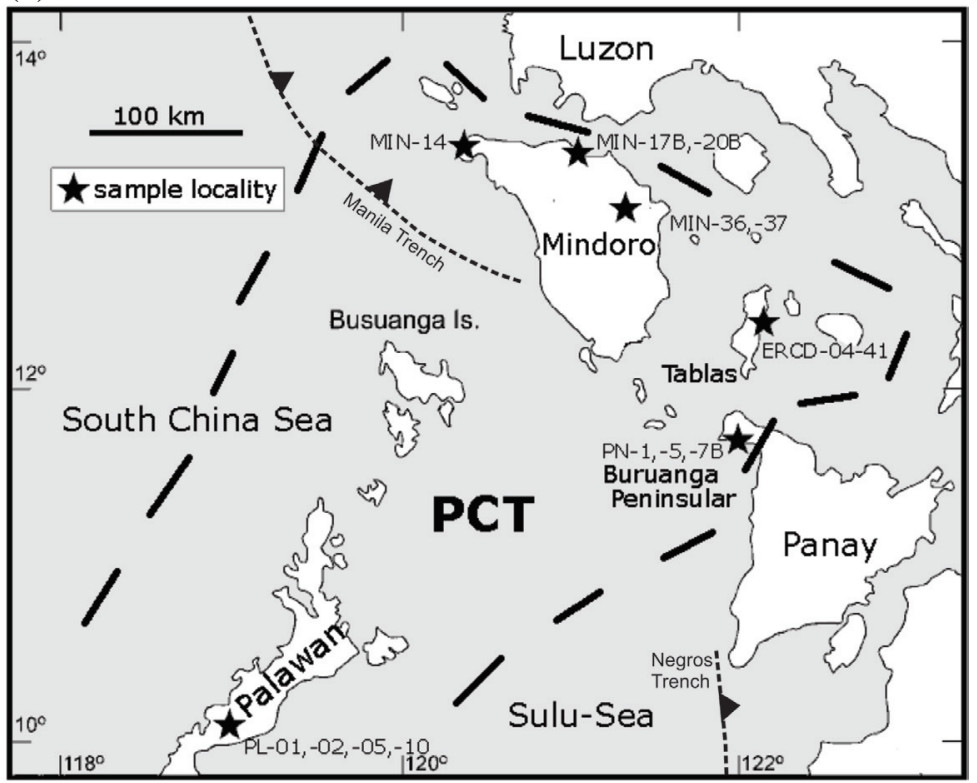

Fig. 1. (a) Tectonic map of the Philippines and location of various trench systems modified from Walia et al. (2013), (b) Map of the northern part of the PCT; bold broken line indicates the boundary of the PCT as currently understood. Stars indicate the origin of the samples used in this study. 
late Cretaceous (ca. 80 - $90 \mathrm{Ma}$ ) the metamorphic complex was intruded by rhyolite dikes (Knittel 2011). Recently it was discovered that metamorphic rocks at the southern and western margins of the Mindoro Metamorphics have significantly younger protolith ages than the bulk of the metamorphic complex (Knittel et al. 2017).

We have studied here two samples from Mindoro that may represent potential sources of zircons found on the other islands, the Camarong Gneiss (MIN-17B, Knittel et al. 2010) and the Cretaceous rhyolite (MIN-20B, Knittel 2011). In addition, we studied three samples of the young metamorphics (MIN-36B, MIN-37A, and MIN-37B, Knittel et al. 2017). These are meta-greywacke samples collected from the south-eastern edge of the metamorphic complex in northern Mindoro. The U-Pb zircon ages for these three samples range from $22 \mathrm{Ma}$ to $2.82 \mathrm{Ga} ; 38$ grains from these three samples were analyzed for their Hf isotopic composition.

\subsection{Tablas}

Southeast of Mindoro, the island of Tablas is located near the eastern margin of the PCT (Fig. 1). Metamorphic basement is exposed in the north and in the south-east of the island and consists of pelitic schists, meta-sandstones, quartzite and several kinds of basic schists derived from lavas, tuffs, and basic siltstones (Faure et al. 1989; Dimalanta et al. 2009). In addition, an ophiolite, the Sibuyan Ophiolite forms the basement upon which Oligocene to Miocene sediments and volcanics were deposited.

Sample ERCD-04-41 (Knittel et al. 2017) is a wellrecrystallized impure quartzite or mica-schist from the northern outcrop of the metamorphic complex. Knittel et al. (2017) dated detrital zircons from this sample and found age patterns suggesting a maximum age of the protoliths of $112 \mathrm{Ma}$. Besides showing major age peaks at $210-260$ and 390 - $430 \mathrm{Ma}$, the sample also contains a number of zircons dated at $1.83-1.90$ and $2.41-2.46 \mathrm{Ga}$.

\subsection{Panay}

The island of Panay is located at the eastern margin of the PCT and only its north-western tip, the Buruanga Peninsular is considered to be part of the PCT (Hamilton 1979; McCabe et al. 1982; Zamoras et al. 2008; Gabo et al. 2009). The trace of the suture is considered to cross the isthmus that connects the peninsular with the main island and is now buried by the Fragante Formation which contains debris from both, the main island of Panay and from the Buruanga Peninsular (Gabo et al. 2009; Walia et al. 2013).

The Buruanga Peninsular consists of alternating chertclastic sequences juxtaposed with limestone blocks forming one or more accretionary complexes. The cherts (Unidos Formation), the clastic sequences (the Saboncogon Formation), and the bedded pelagic limestone (the Gibon Forma- tion) are of Triassic to Jurassic age (Zamoras et al. 2008). On the basis of radiometric age determinations, Walia et al. (2013) suggested that collision of the PCT with the PMB started at $\sim 14$ Ma resulting in uplift and rapid erosion as the result of subduction of low-density crustal rocks and ended at 7 - $8 \mathrm{Ma}$ with isostatic re-equilibration of the sediments overlying the former suture zone. The suture is now covered by the sediments of the Fragante Formation.

Our samples from the island Panay come from distinctly different sources: Sample PN-5 is a middle to late Jurassic sandstone of the Saboncogon Formation and is considered to reflect input from the continental margin as the oceanic plate approached the Asian continent (Zamoras et al. 2008; Gabo et al. 2009; Walia et al. 2013). The U-Pb ages of the zircons contained therein range from $228 \mathrm{Ma}$ to $2.38 \mathrm{Ga}$ (Walia et al. 2013). A major fraction shows an almost continuous spectrum of ages from 228 to $297 \mathrm{Ma}$. These zircons are thought to be related to the igneous episode identified by Knittel et al. (2010) in Mindoro and by Li et al. (2012a) in Late Permian to Triassic sediments in south-eastern China.

Samples PN-7B and PN-01 contain the youngest zircons studied here (18 - $21 \mathrm{Ma})$. Sample PN-7B, a tuffaceous sandstone comes from the Fragante Formation, a syn- to post-collisional deposit that apparently contains clastic components from both the PCT and the Philippine Mobile Belt (Gabo et al. 2009; Walia et al. 2013). Sample PN-01 comes from the 18 Ma Patria Intrusion, a fine to medium grained quartz diorite of uncertain tectonic position.

\subsection{SE China Block}

SE China is considered to be the source of the quartzrich sediments found within the PCT (Suzuki et al. 2000; Gabo et al. 2009) as, prior to the opening of the South China Sea at about 32 - 16 Ma (Taylor and Hayes 1983), the PCT was part of the continental margin of SE China. SE China is constituted of the Cathaysia Block, which together with the Yangtze Block forms the South China Block (Fig. 2). The former actually may comprise two blocks comprising the north-eastern part and the south-western part of Cathaysia, respectively (e.g., Yu et al. 2009; Deng et al. 2017). The South China Block is separated from the North China Block to the north by the Qinling-Dabie-Sulu orogenic belt and from the Indochina Block to the south by the Ailaoshan-Red River Fault. Potentially, all three blocks, i.e., the Yangtze Block, the north-eastern and the south-western Cathaysia Blocks, and the North China Block might have contributed to the zircon inventory of the PCT as shown by the discussion of the sediment sources of Taiwan (e.g., Lan et al. 2016; Deng et al. 2017).

In a seminal paper on the $\mathrm{U}-\mathrm{Pb}$ ages and $\mathrm{Hf}$ isotopic compositions of detrital zircons from the Cathaysia Block, $\mathrm{Xu}$ et al. (2007) investigated zircons separated from river sediments of the Ou River (Oujiang) in the north-eastern 


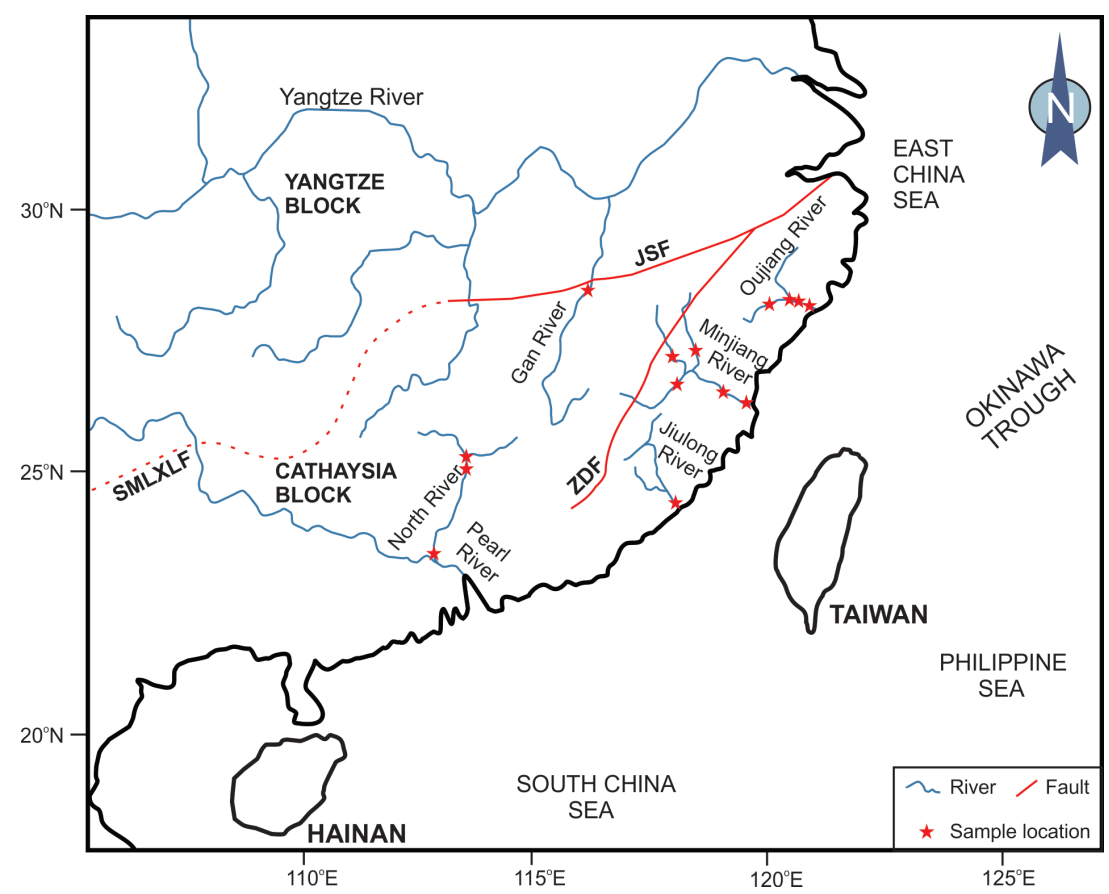

Fig. 2. Simplified map of SE China showing the approximate boundaries between the Cathaysia Block (CB) and the Yangtze Block (YB) as well as major rivers draining the Cathaysia Block. Stars indicate sample localities of Xu et al. (2007, 2014, 2016). JSF is the Jiang-Shao Fault and SMLXLF is the Shizong-Mile-Luoping-Xinyi-Luodian Fault and both define the boundary between the CB and YB. ZDF is the Zhenghe-Dapu Fault dividing the Cathaysia Block into two parts.

part of the Cathaysia Block and the North River (Beijiang), a tributary of the Pearl River, in the south-western part of the Cathaysia Block (Fig. 2). Subsequently Xu et al. (2014, 2016) studied the Min River (Minjiang River) which also drains the north-eastern part of Cathaysia and the Jiulong River in the south-western part of Cathaysia. Their data provide a fairly concise record of the age-structure of the crust underlying the catchment areas as shown by the compilations of age data by Xu et al. (2016) and Deng et al. (2017).

In the Ou River samples, Xu et al. (2007) recognized only two major peaks in the age distribution curve at 130 - $150 \mathrm{Ma}$ and at $1.84-1.86 \mathrm{Ga}$. In addition, minor peaks occur at ca. 110 and $210-250 \mathrm{Ma}$ and at $2.00-2.06$ and 2.11 $-2.18 \mathrm{Ga}$. Virtually no grains occur in the range $270 \mathrm{Ma}$ to $1.65 \mathrm{Ga}$ (Fig. 3). In the Min River, Xu et al. (2014, 2016) recognized significant peaks at 100,140 - $150 \mathrm{Ma}$, similar to the Ou River spectrum, but also major peaks at 200 - 240 and 400 - 440 Ma. For Precambrian time, the Min River zircons exhibit a broad peak between $1.65-1.90 \mathrm{Ga}$ and numerous small peaks for the period $2.2-2.6 \mathrm{Ga}$. The Jiulong River zircons define peaks at ca. 110, 140 - 170, and $220-240 \mathrm{Ma}$ and thus display a similar spectrum to the Min River. Only few grains of Precambrian ages were found in these. The North River zircons exhibit numerous smaller peaks at ca. $160 \mathrm{Ma}$ and at ca. $240 \mathrm{Ma}$, as well as peaks at $1.1-1.8 \mathrm{Ga}$ (for this period very few zircons exist in the other rivers) and between $2.45-2.8 \mathrm{Ga}$.

In summary, records of Yanshanian (90 - $160 \mathrm{Ma})$ and
Indosinian (200 - $250 \mathrm{Ma}$ ) age-spectra are found in all rivers draining the Cathaysia Block, whereas a significant Caledonian ( 490 - $390 \mathrm{Ma}$ ) zircon population is found only in the Min River [also in the Gan River that drains into the Yangtze River (He et al. 2013)], and the North River. With regard to the Precambrian zircon age populations, Ou and Min Rivers are dominated by peaks at $1.84-1.88 \mathrm{Ga}$ that are essentially absent in the Gan, Jiulong, and North Rivers. These differences in the age distribution curves led $\mathrm{Xu}$ et al. $(2007,2014,2016)$ to suggest that Cathaysia consists of two terranes separating a north-eastern part from a southwestern part. Yu et al. (2010) suggested that the boundary between these two blocks likely trends west-east and separates the north-eastern Wuyishan area from the south-western Nanling Terrane.

\section{ANALYTICAL METHODS}

In situ Hf isotope measurements were performed on zircons previously dated by LA-ICP-MS U-Pb dating. The $\mathrm{Hf}$ isotopic analysis was conducted using the Nu Plasma HR Multi-Collector Inductively-Coupled plasma Mass Spectrometry (MC-ICP-MS) connected to the Photon Machines Analyte G2 laser system at the Institute of Earth Sciences, Academia Sinica, Taipei. Each measurement, with a beam diameter of $50 \mu \mathrm{m}$, a $5-8 \mathrm{~Hz}$ repetition rate, and laser energy density of $\sim 8-9 \mathrm{~J} \mathrm{~cm}^{-2}$, took $\sim 2$ minutes including the blank time of $30 \mathrm{~s}$ and the ablation time of $\sim 85 \mathrm{~s}$. The laser ablation 

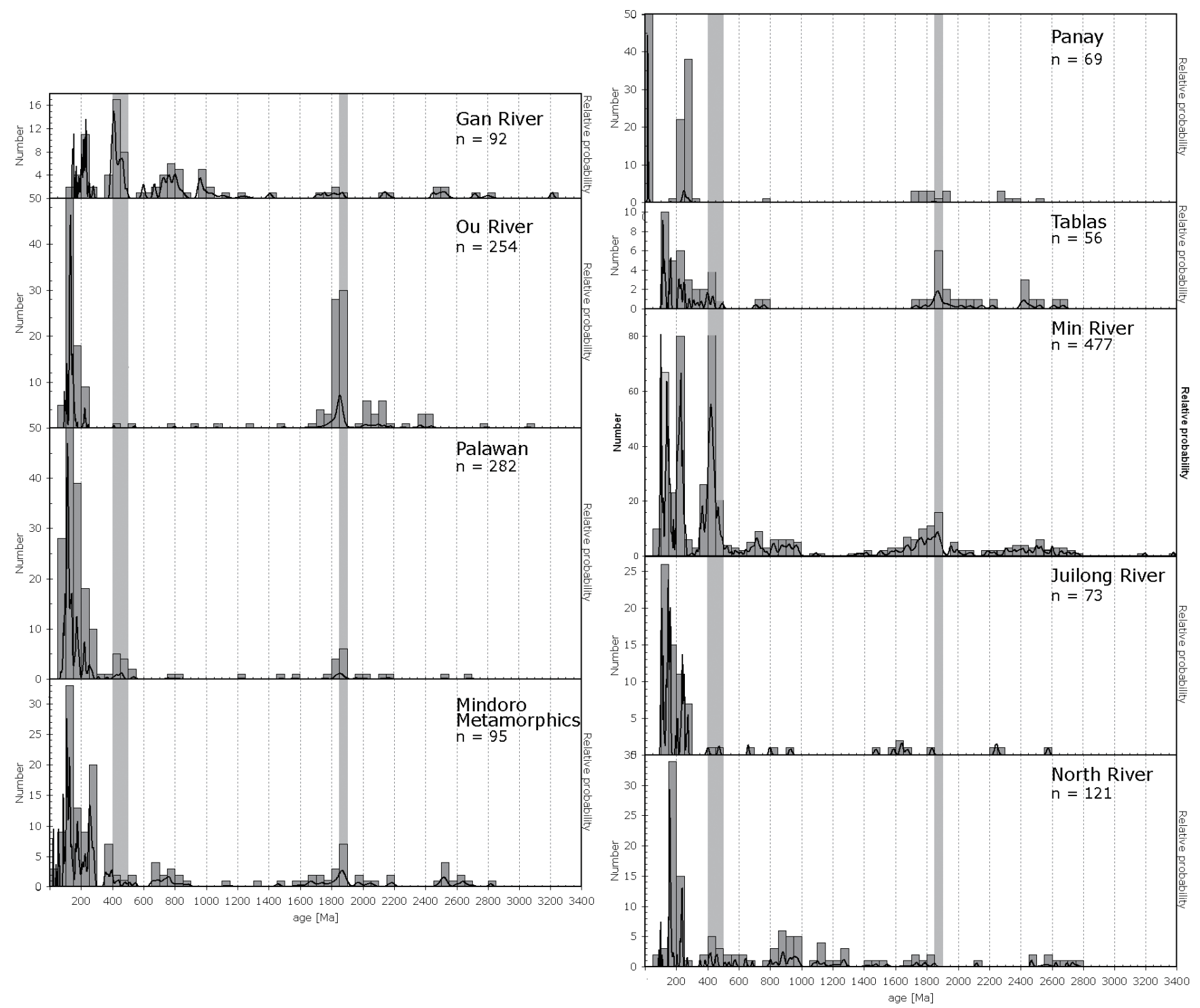

Fig. 3. Histograms and probability density plots for dated zircons from the PCT and rivers draining the Cathaysia Block. Data sources: Knittel et al. (2010, 2017), Knittel (2011), Walia et al. (2012, 2013) for the PCT, and Xu et al. (2007, 2014, 2016) for the Cathaysia Block.

was performed with He carrier gas of $\sim 0.9 \mathrm{~L} \mathrm{~min}^{-1}$ (MFC1 $=$ $\sim 0.7 \mathrm{~L} \mathrm{~min}^{-1}$ and MFC2 $=\sim 0.2 \mathrm{~L} \mathrm{~min}^{-1}$ ) which would then mix with an Ar gas of $\sim 0.7 \mathrm{~L} \mathrm{~min}^{-1}$. The laser ablation was performed with helium carrier gas that can substantially reduce the deposition of ablated material onto the sample surface and greatly improve transport efficiency, and thus increase the signal intensities (Günther and Heinrich 1999).

Accuracy of the analytical data was evaluated by analysing the Mud Tank (MT) zircon standard with the unknowns during the analysis, which yielded an average ${ }^{176} \mathrm{Hf} /{ }^{177} \mathrm{Hf}$ ratio of $0.282532 \pm 39(\mathrm{n}=43)$. This value is in good agreement with the average ${ }^{176} \mathrm{Hf} /{ }^{177} \mathrm{Hf}$ value reported in literature which is $0.282504 \pm 44 ; n=158$ (Woodhead and Hergt 2005). Detailed analytical information is provided by Wu et al. (2006).

The $\varepsilon \operatorname{Hf}(\mathrm{T})$ value is parts in $10^{4}$ deviation of the ini- tial ${ }^{176} \mathrm{Hf} /{ }^{177} \mathrm{Hf}$ isotopic ratios of the sample from the chondritic uniform reservoir and $\mathrm{T}_{\mathrm{DM}}{ }^{\mathrm{c}}$ is the zircon $\mathrm{Hf}$ isotope "crustal" model age based on a depleted-mantle source and the assumption that the protoliths of the zircon's host magma have the average continental crustal ${ }^{176} \mathrm{Lu} /{ }^{177} \mathrm{Hf}$ ratio of 0.015 following Griffin et al. (2002). The ${ }^{176} \mathrm{Lu}$ decay constant adopted for the calculations is $1.865 \times 10^{-11} \mathrm{y}^{-1}$ as suggested by Scherer et al. (2001). Our calculations would not significantly differ in values if the alternative decay constants proposed by more recent studies were used.

\section{RESULTS}

Hf isotopic compositions were measured for 188 concordant zircon grains that have previously been dated using the U-Pb dating technique (Knittel et al. 2010, 2017; Knittel 
2011; Walia et al. 2012, 2013). The U-Pb dating results are compiled in Fig. 3. As pointed out in the previous studies, almost all zircons have $\mathrm{Th} / \mathrm{U}>0.1$ and the majority of the grains exhibit oscillatory zoning, both features suggesting magmatic origins. The zircons were separated from 13 samples collected on the islands Palawan, Panay, Tablas, and Mindoro. The results are listed in Tables S1 and S2 (supplementary data). The U-Pb ages and $\mathrm{Th} / \mathrm{U}$ ratios are from Knittel et al. (2010, 2017), Knittel (2011), and Walia et al. $(2012,2013)$.

\subsection{Palawan}

62 zircon grains previously dated by the U-Pb method were analyzed for their $\mathrm{Hf}$ isotope composition. The zircons in the range 80 - 91 Ma have restricted positive $\varepsilon H f(T)$ values ranging from +0.4 to +15.5 whereas one grain dated at $93 \mathrm{Ma}$ has a negative value of -2.6. The zircons in the age range 110 - $130 \mathrm{Ma}$ have $\varepsilon \mathrm{Hf}(\mathrm{T})$ values covering a wide range from -12.6 to +7.6 .

Permian zircons that are prominent in Mindoro and Panay, are also to be found in our Palawan samples (12 grains; 235 - $274 \mathrm{Ma}$ ), though they largely escaped the sampling of Suggate et al. (2014). Four grains in the age range 250 - 260 Ma have similar positive $\varepsilon \mathrm{Hf}(\mathrm{T})$ in the range +4.3 to +14.4 (Fig. 4 a).

The next significant group of zircons covers the period from 402 - 465 Ma (Walia et al. 2012; Suggate et al. 2014). Seven grains were analyzed for their Hf isotopic composition and were found to have $\varepsilon \mathrm{Hf}(\mathrm{T})$ of -11.5 to +15.6 . There are
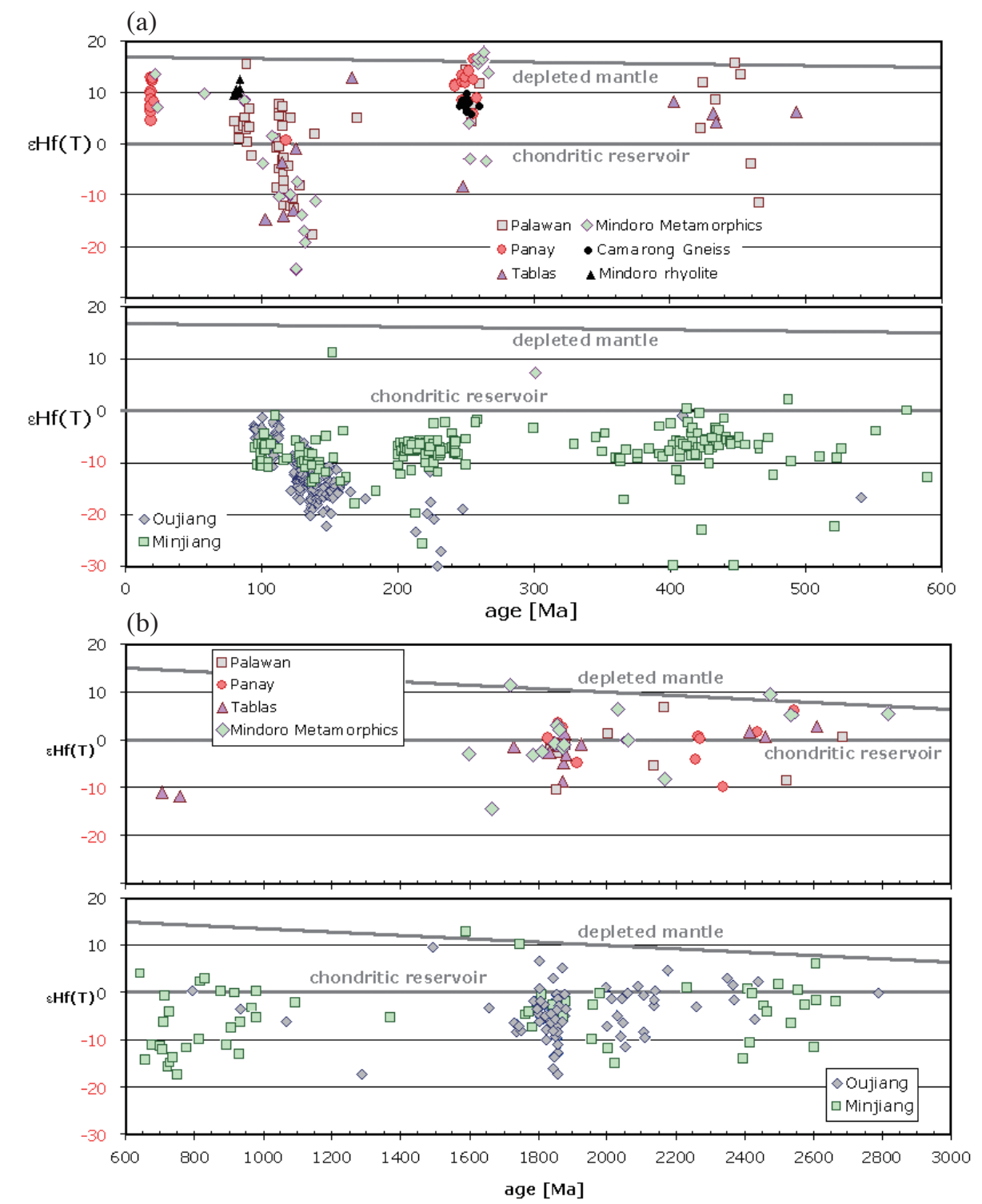

Fig. 4. $\varepsilon \mathrm{Hf}(\mathrm{T})$ plotted versus age for zircons (a) younger than $1 \mathrm{Ga}$, (b) older than $1 \mathrm{Ga}$ for samples from the PCT (upper panel) and rivers draining the Cathaysia Block (lower panel). Data sources are the same as in Fig. 3. 
only very few zircons in the age range between $465 \mathrm{Ma}$ and $1.83 \mathrm{Ga}$, which do not form any discernible cluster (Walia et al. 2012; Suggate et al. 2014). Nine zircons dated at ca. 1.83 $1.87 \mathrm{Ga}$ have $\varepsilon \mathrm{Hf}(\mathrm{T})$ ranging from -10.4 to +22.0 . Five grains in the age range $2.0-2.7 \mathrm{Ga}$ have $\varepsilon \mathrm{Hf}(\mathrm{T})$ values between -8.5 and +6.7 (Fig. 4b).

\subsection{Mindoro}

We have determined the Hf isotope composition for 14 grains of sample MIN-17B that represent the $252 \pm 3 \mathrm{Ma}$ Camarong Gneiss and find a range in $\mathrm{\varepsilon Hf}(\mathrm{T})$ of +5.8 to +9.8 with a mean value of $+7.6 \pm 0.6$ (Fig. $4 \mathrm{a}$ ). Five co-magmatic zircons dated at $80-84 \mathrm{Ma}$ were analyzed for the rhyolite sample MIN-20B. $\varepsilon \mathrm{Hf}(\mathrm{T})$ ranges from +9.5 to +12.5 . In addition, the Hf isotopic compositions of 2 xenocrystal zircons, dated at 177 and $258 \mathrm{Ma}$, were determined for this sample. For these zircons $\varepsilon \mathrm{Hf}(\mathrm{T})$ values are +11.4 and +6.5 .

Sample MIN-37B contains two unusually young zircons (22 and $24 \mathrm{Ma}$, respectively) which have fairly depleted $\varepsilon \mathrm{Hf}(\mathrm{T})$ values of +13.5 and +7.0 , respectively. The youngest zircon age obtained for sample MIN-37A is $58 \mathrm{Ma}$ for which the $\varepsilon \mathrm{Hf}(\mathrm{T})$ value is positive at +9.8 . The next older grain is dated at $87 \mathrm{Ma}$ with $\varepsilon \mathrm{Hf}(\mathrm{T})$ of +8.6 . Ten zircons in the range $101-140 \mathrm{Ma}$ have all negative $\varepsilon \mathrm{Hf}(\mathrm{T})$ values between -3.8 and -24.5 with one exception (MIN-37B_06: $\varepsilon \mathrm{Hf}(\mathrm{T})=+1.4)$. Eight zircons in the range $252-267 \mathrm{Ma}$ have mostly high positive values of $\varepsilon \mathrm{Hf}(\mathrm{T})$ in the range +13.8 to +17.9 though a few grains have values in the range -3.4 to +3.9. The $1.60-1.87 \mathrm{Ga}$ old zircon grains have $\varepsilon \mathrm{Hf}(\mathrm{T})$ values between +11.4 and -14.3 . Six Paleoproterozoic grains have $\mathrm{U}-\mathrm{Pb}$ ages between 2.03 and $2.81 \mathrm{Ga}$ and the $\varepsilon \mathrm{Hf}(\mathrm{T})$ values are between 0.0 and +9.6 , while one grain dated at $2.16 \mathrm{Ga}$ (MIN-36B_02) has $\varepsilon \mathrm{Hf}(\mathrm{T})$ as -8.0 (Fig. 4b).

\subsection{Tablas}

Five grains have U-Pb zircon ages in the range of 103 - $125 \mathrm{Ma}$ and $\varepsilon \mathrm{Hf}(\mathrm{T})$ ranging from -1.0 to -14.8 . A single grain dated at $248 \mathrm{Ma}$ has negative $\operatorname{EHf}(\mathrm{T})$ of -8.2 , in contrast to the $\varepsilon \mathrm{Hf}(\mathrm{T})$ values of Permian grains from Panay and Palawan islands (Fig. 4a). Five grains form a small group in the age range of $403-493$ Ma. Four out of these were analyzed here and have positive $\varepsilon \mathrm{Hf}(\mathrm{T})$ between +4.1 and +8.1 . Two grains dated at 706 and $758 \mathrm{Ma}$ have $\varepsilon \mathrm{Hf}(\mathrm{T})$ of -11.0 and -11.8 , respectively. The $1.73-1.92 \mathrm{Ga}$ zircons have negative $\varepsilon \mathrm{Hf}(\mathrm{T})$ values $(-0.8$ to -8.7$)$ except for one grain dated at $1.87 \mathrm{Ga}$ which has the positive $\varepsilon \mathrm{Hf}(\mathrm{T})$ of +1.3 . Three Paleoproterozoic grains dated at $2.4-2.6 \mathrm{Ga}$ have positive $\varepsilon \mathrm{Hf}(\mathrm{T})$ values between +0.7 and +2.8 .

\subsection{Panay}

Sample PN-5 represents the Jurassic Saboncogon For- mation and contains mostly zircons ranging in the age from 242 - $256 \mathrm{Ma}$. Twelve grains were analyzed for their Hf isotopic composition and all have positive $\varepsilon \mathrm{Hf}(\mathrm{T})$ values in the range +5.7 to +16.4 (Fig. $4 a$ ) .

Zircons of Paleoproterozoic age fall into two groups, a younger one in the range $1.82-1.91 \mathrm{Ga}$ (10 grains) and an older one in the range $2.18-2.43 \mathrm{Ga}$ (3 grains). Six zircons of the younger group analyzed for their $\mathrm{Hf}$ isotopic composition have $\varepsilon \mathrm{Hf}(\mathrm{T})$ in the range of -4.8 to +3.5 , whereas the values found for the three grains of the older group lie close to the chondritic values $[\varepsilon \mathrm{EH}(\mathrm{T})=+0.1$ to +1.6$]$ (Fig. 4b).

Sample PN-7B collected from the Fragante Formation contains young zircons $(18-21 \mathrm{Ma})$ that are thought to be derived from the PMB. These have positive $\varepsilon \mathrm{Hf}(\mathrm{T})=+6.2$ to +12.9 , whereas three Paleoproterozoic zircons dated at $2.25,2.34$, and $2.54 \mathrm{Ga}$ have $\varepsilon \mathrm{Hf}(\mathrm{T})$ of $-4.2,-9.9$, and +6.1 , respectively.

Zircons from the $18 \mathrm{Ma}$ Patria Intrusion have $\varepsilon \mathrm{Hf}(\mathrm{T})$ values ranging from +4.5 to +10.1 though all zircons have the same age (18.0 - 18.7 Ma), i.e., in all probability are not xenocrysts. Overall, the values are slightly lower than those of the young zircons in sample PN-7B and should represent roughly the range of values expected for arc volcanics from this area (Fig. 4a).

\section{DISCUSSION}

While it is considered as an established fact that the PCT was a part of the SE China margin prior to the opening of the South China Sea, the location of the PCT relative to continental area is not well established, though Walia et al. $(2012,2013)$ suggested a location close to the Wuyishan area based on the data for Cathaysia provided by Xu et al. (2007). A more detailed picture can be obtained using the additional detrital zircon data for the major rivers draining the Cathaysia Block provided by Xu et al. $(2014,2016)$. Comparison of the age data in Fig. 3 shows that Yanshanian and Indosinian zircons are to be found in all samples. However, the samples from the PCT contain a more or less pronounced Caledonian zircon population (400 - $440 \mathrm{Ma}$ ) and a Paleoproterozoic population at ca. $1.85-1.90 \mathrm{Ga}$ that is not present in southern and western Cathaysia. Hence this area is considered as unlikely source area. Among the northern rivers, the Min River exhibits the closest resemblance to the PCT zircon age spectra.

In the following, the data obtained in this study are compared with data for detrital zircons from recent river sediments from SE China. Based on the compilation of detrital zircon data from river sediments and older sediments by Deng et al. (2017), we concur with the conclusions of these authors that river sediments probably are more representative for the catchment area(s) than compilations of data for detrital zircons contained in sedimentary rocks. However, in contrast to the authors above, it is thought unlikely that the 
contributions from certain areas can be quantified on this basis, given the variability in single rivers as demonstrated by $\mathrm{Xu}$ et al. (2007). It is also clear that during deposition of the investigated sedimentary rocks, the current river systems very probably did not yet exist. Hence the comparisons provided here imply a comparison to the general catchment areas or larger crustal blocks.

\subsection{Early Miocene (18 - 20 Ma)}

Our youngest age group, $18-20 \mathrm{Ma}$, comes from Panay and is not found in SE China. Zircons of that age are considered to be related to igneous activity of the PMB and provide a useful background value of what Hf isotope compositions are to be expected for arc related magmas. Eighteen zircons, ranging in ages from $18-21 \mathrm{Ma}$, analyzed for their $\mathrm{Hf}$ isotope represent a pre-collision intrusion (PN-01) and a post collision tuffaceous sandstone (PN-7B; Walia et al. 2013). In addition, two slightly older zircons (dated at 22 and $24 \mathrm{Ma}$ ) were found in young metamorphic rocks on Mindoro (MIN-37B). These zircons all have positive $\varepsilon \mathrm{Hf}(\mathrm{T})$ values in the relatively restricted range between +4.5 and +12.9 (Fig. 4a); i.e., they fall between evolution lines for the depleted mantle (DM) and a chondritic reservoir (CHUR). Model ages $\mathrm{T}_{\mathrm{DM}}{ }^{\mathrm{C}}$ lie between 205 - 530 Ma but probably have no significance because the $\mathrm{Hf}$ isotopic compositions are likely the result of mixing between depleted mantle and enriched components derived from subducted sediment.

\subsection{Late Cretaceous (80 - 93 Ma)}

Eighteen zircon grains in the age group $80-93 \mathrm{Ma}$ were analyzed for their Hf isotopic composition. These zircons were found in all four samples of Cretaceous metasediments in Palawan and also in the Mindoro samples. Except for the oldest grain PL-05_52, [93 Ma, $\varepsilon \mathrm{Hf}(\mathrm{T})=-2.6]$, all the grains have positive $\varepsilon \mathrm{Hf}(\mathrm{T})$ values in the range +0.4 to +15.5 , with majority having values between +0.4 and +6.8 . These zircons are considered to be related to rhyolite volcanism that was widespread in SE China at that time and relics of which are also be found in Mindoro (Knittel 2011). Our sample of the Mindoro rhyolite (MIN-20B) has $\varepsilon \mathrm{Hf}(\mathrm{T})$ in the upper part of the range observed for the detrital zircons $(+9.5$ to +12.5$)$. In SE China, a potentially corresponding group is slightly older and comprises zircons dated at about 90 - $110 \mathrm{Ma}$. Zircons of this group are found in all the river systems studied so far, but are prevalent in the Ou River. They have a rather restricted range in $\varepsilon \mathrm{Hf}(\mathrm{T})$ of about -11 to +2 , lower than the values observed for the zircons from the PCT. Zircons from the Min River occupy the lower range between -11 and -5 (Fig. 4a).

Thus, detrital zircons from Palawan and Mindoro in terms of Hf isotopic composition lie between those from mainland China and those from the Mindoro rhyolite. This suggests that they contain a larger component of mantle-input than the zircons from mainland China and the Mindoro rhyolite represents the extreme case together with detrital zircon PL-02_01, which has $\varepsilon H f(T)=+15.5$. The differences in $\varepsilon \mathrm{Hf}(\mathrm{T})$ of detrital zircons from mainland China and the PCT suggests that the latter are derived from local sources that are represented by rhyolite sample MIN-20B.

\subsection{Mid-Early Cretaceous (101 - $140 \mathrm{Ma})$}

Our next group comprises zircons having crystallization ages of $101-140 \mathrm{Ma}$. These grains come from the Cretaceous metasediments of Palawan, Tablas and the young Mindoro Metamorphics. These zircons exhibit a wide range of $\varepsilon \mathrm{Hf}(\mathrm{T}$ ) values ranging from -25 to +7.6 (Fig. 4a) but most values, in particular those for grains older than $120 \mathrm{Ma}$, are negative suggesting derivation of the magmas from crustal sources. In SE China the corresponding group covers the age range of about $120-170 \mathrm{Ma}$. $\varepsilon \mathrm{Hf}(\mathrm{T})$ in this group is likewise very variable ranging from -20 to +2 . There are distinct regional differences. Zircons from the Ou River span the whole age range and $\varepsilon \mathrm{Hf}(\mathrm{T})$ values are generally low (-20 to -5$)$. Zircons from the Min River cover the same age range but $\varepsilon \mathrm{Hf}(\mathrm{T})$ is more restricted $[\varepsilon \mathrm{Hf}(\mathrm{T})=-15$ to -5 ]

\subsection{Triassic (200 - 250 Ma) to Late Permian (245 - $270 \mathrm{Ma})$}

In SE China, the next group ranges from $200-250 \mathrm{Ma}$ representing the Triassic Indosinian magmatism (Fig. 4a). This age group is most prominent in the Min River samples and here exhibits a rather restricted range in $\varepsilon \mathrm{Hf}(\mathrm{T})(-12$ to -5) (Xu et al. 2014, 2016). Some zircons occur in the $\mathrm{Ou}$ River sample and these have very low $\varepsilon \mathrm{Hf}(\mathrm{T})$ of -30 to -18 . Zircons for this period are almost completely absent in the samples of the PCT studied here, but slightly older zircons of late Permian age (ca. 245 - $270 \mathrm{Ma}$ ) were found in our samples from Palawan, Tablas, Panay, and from the young metamorphics from Mindoro (Fig. 4a).

The detrital zircons from the Jurassic Saboncogon Formation on Buruanga Peninsular, Panay, and the metasediments from Palawan have all positive $\varepsilon \mathrm{Hf}(\mathrm{T})$ values in the range +4 to +16.4 , whereas those from the Mindoro Metamorphics have two grains with negative $\varepsilon \mathrm{Hf}(\mathrm{T})$ and altogether cover the range -3.4 to +17.9 . For MIN-20B, a xenocryst grain dated at $258 \mathrm{Ma}$ was analyzed for $\varepsilon \mathrm{Hf}(\mathrm{T})$ and also has a positive value of +6.5 . The zircons of the Camarong Gneiss in Mindoro (MIN-17B), studied by Knittel et al. (2010), have $\varepsilon \mathrm{Hf}(\mathrm{T})$ values in the range +5.8 to +9.8 , i.e., fall into the range of the detrital zircons and thus support the suggestion that the detrital zircons are related to the magmatic episode that also produced the Camarong Gneiss (Walia et al. 2012, 2013). Li et al. (2006, 2012b) and Knittel et al. (2010) suggest that these zircons are related to igneous 
activity that heralds the onset of westward directed subduction below SE China. The observed difference in ages (245 - $270 \mathrm{Ma}$ in the PCT vs. 200 - $250 \mathrm{Ma}$ in mainland China) and decreasing $\varepsilon \mathrm{Hf}(\mathrm{T})$ would suggest an inland movement of the arc with time resulting in higher contributions of the crust to the magmas.

Zircons of late Permian age are very rare in the SE China river sediments (Fig. 4a). However, Li et al. (2012a), who studied late Permian sediments from Fujian, Jiangxi, Hunan, and Guangdong Provinces of south-eastern South China, found zircons in the range $256-290 \mathrm{Ma}$ with $\varepsilon \mathrm{Hf}(\mathrm{T})$ in the range -6.7 to +14.9 .

These relationships can be explained as follows: if it is accepted that in Permian time a magmatic arc formed in response to the initiation of subduction along the south-eastern margin of SE China, the sediments deposited in Palawan and Panay were likely sourced from igneous rocks that were produced on the ocean-ward side of the orogen, similar to the protoliths of the Camarong Gneiss, and hence from igneous rocks that likely contain largely mantle-sourced materials. The assumed dominance of mantle sources is supported by the fact that Knittel et al. (2010) did not find any inherited (from the source area) or xenocrystal (picked up by the magma during ascent) zircons in the Permian Camarong Gneiss and Li et al. (2006) found only a single xenocrystal zircon in the Permian Hainan pluton. In contrast, sediments sampled by Li et al. (2012a) were sourced from the continent-ward portion of the Permian arc and contain more zircons derived from recycled crustal material due to crustal contamination and perhaps also re-melting of older crust.

\subsection{Early Paleozoic (400 - 465 Ma)}

The next age group, i.e., zircons ranging in age from 400 - $465 \mathrm{Ma}$, was found only in our samples from Palawan (405 - $465 \mathrm{Ma}, \mathrm{n}=7)$ and Tablas (403 - $434 \mathrm{Ma}, \mathrm{n}=3)$, but not in those from Panay and the young Mindoro Metamorphics (Walia et al. 2012, 2013; Knittel et al. 2017). Zircons of this age were also not found in the Ou River sediments, but are present in the Min-River, where they form a prominent group that ranges from about 400 - 450 Ma characterized by $\varepsilon \mathrm{Hf}(\mathrm{T}$ ) in the range -10 to -2 (Xu et al. 2007, 2014, 2016). This is in contrast to the zircons from Palawan and Tablas, which have mostly $\varepsilon \mathrm{Hf}(\mathrm{T})$ in the range +3 to +16 (Fig. 4a), i.e., while the zircons from Cathaysia are mainly derived from mixed mantle-crustal magmas, those from the PCT reflect significant mantle input as they are derived from sources that formed closer to the trench. This is supported by data of Li et al. (2012a), who found zircons in the range 420 - 479 Ma in Late Permian sediments in SE China. These zircons have $\varepsilon \mathrm{Hf}(\mathrm{T})$ from -16.1 to +14.1 , i.e., these zircons cover about the same range as the zircons from Palawan, Tablas and the Min-River zircons. Li et al. (2012a) consider these zircons to be sourced from Early Paleozoic granites formed during the Caledonian-aged Wuyi-Yunkai Orogeny, which are widespread in south-eastern China (see Fig. 1 and review in Wang et al. 2007).

\subsection{Late Proterozoic (600 - $1000 \mathrm{Ma)}$}

Zircons in the range $600-1000 \mathrm{Ma}$, which are abundant in the rivers draining Cathaysia, are not observed in our samples from PCT, except for two grains from Tablas. $\varepsilon \mathrm{Hf}(\mathrm{T})$ values in Cathaysia typically scatter between +10 and -18 thus reflecting production of crustal melts with significant mantle input. The two grains from Tablas have $\varepsilon \mathrm{Hf}(\mathrm{T})$ of about -11 .

\subsection{Paleoproterozoic (1.8 - 1.9 Ga)}

A major age population is formed by zircons dated at $1.81-1.92 \mathrm{Ga}$ which are found in most of the samples from the PCT. Zircons of this age are found almost everywhere in east Asia, including Japan (Tsutsumi et al. 2003, 2006) and Borneo (Van Hattum et al. 2006). Altogether 25 zircons of this age group were selected for Hf isotope analysis. They mostly have $\varepsilon \mathrm{Hf}(\mathrm{T})$ values in the range between -10 and +5 [with one exception, that has $\operatorname{\varepsilon Hf}(\mathrm{T})=+22$ ] . Zircons of the ca. $1.86 \mathrm{Ga}$ event found in the Ou River and Min River samples have somewhat more variable initial ${ }^{176} \mathrm{Hf} /{ }^{177} \mathrm{Hf}$ isotopic compositions with $\varepsilon \mathrm{Hf}$ ranging from -17 to +7 , but most values fall in the negative range. This suggests that at ca. $1.86 \mathrm{Ga}$ magmatism largely recycled older crust with only minor contributions from the mantle. Yu et al. (2009) studied the potential source rocks of the ca. $1.86 \mathrm{Ga}$ zircons in the northern Wuyishan area where plutonic rocks of that age are exposed. They reported a range of -0.4 to -7.4 for $\varepsilon \mathrm{Hf}(\mathrm{T})$ and confirmed the earlier conclusion of $\mathrm{Xu}$ et al. (2007) that the $1.86 \mathrm{Ga}$ orogeny largely recycled older crust. Given the similar range in $\varepsilon \mathrm{Hf}$, it is very likely that the zircons found in our samples have the same sources as those found in the $\mathrm{Ou}$ and Min River sediments, i.e., are derived from the Wuyishan area.

\subsection{Paleo-Mesoproterozoic (2.0 - 2.8 Ga)}

Zircons of the oldest age group in our samples comprise 20 zircons in the range $2.00-2.82 \mathrm{Ga}$. These zircons were found in all sampled areas. These grains have a wide range of $\varepsilon \mathrm{Hf}(\mathrm{T})$ values ranging from -10 to +10 . Zircons from the rivers draining the Cathaysia Block have a similar range in $\varepsilon \mathrm{Hf}(\mathrm{T})$ though values extent to about -15 and positive values rarely exceed +5 (Fig. $4 b$ ).

Based on a review of 4041 zircons from the Cathaysia Block, Southeast China, Li et al. (2014) found a major peak at ca. $2.49 \mathrm{Ga}$. These authors concluded that zircons older than ca. 2.3 Ga are not indigenous to the Cathaysia Block but rather were derived from unknown Archean 
blocks/terranes by long-distance transportation. Alternatively, other authors have suggested that these zircons indicate the presence of currently not exposed or already eroded Archean lithologies within the Cathaysia Block (e.g., Xu et al. 2007; Yu et al. 2010). Similar to the ca. 1.86 Ga zircons, those dated at ca. $2.4 \mathrm{Ga}$ and older are found almost everywhere in east Asia, including Japan (e.g., Tsutsumi et al. 2003, 2006) and Borneo (Van Hattum et al. 2006). Hence their presence does not yield much information on the sources of the zircons in the PCT. Nevertheless, we note that based on the compilation of Li et al. (2014), the zircons found in the PCT altogether have higher $\varepsilon \mathrm{Hf}(\mathrm{T})$ than the samples from the Cathaysia Block.

\section{CONCLUSIONS}

Zircons found in the meta-sediments of the PCT exhibit age ranges also found in SE China. However, contemporaneous zircons from the PCT often have higher $\varepsilon \mathrm{Hf}(\mathrm{T})$ compared to their counterparts from SE China, reflecting derivation from igneous rocks that are derived from sources that have higher input from the mantle. This is particularly evident for zircons in the age ranges $80-93,245$ - 270, and 400 - $465 \mathrm{Ma}$. This relationship is considered to reflect the relative positions of the source areas: zircons from the PCT are derived largely from the ocean-facing side of the magmatic arc, which perhaps is not underlain by thick, old continental crust but rather by younger sediments of accretionary wedges. The differences in the Hf isotopic composition of zircons produced during corresponding episodes in the PCT in SE China suggests that they are largely derived from local sources. Some age groups observed in river sediments from SE China are not found in the PCT, e.g., zircons in the age range 200 - 245, 340 - $400 \mathrm{Ma}, 600 \mathrm{Ma}-1.6 \mathrm{Ga}$. Transport of some of these zircons might have been prevented by the $250-270 \mathrm{Ma}$ arc that might have blocked sediment input from mainland China. In addition, it is speculated that the Permo-Triassic arc migrated inland; hence there are no 200 - 240 Ma zircons in the PCT.

Acknowledgements We wish to dedicate this paper to the memory of Prof. Tsanyao Frank Yang, who initiated our work on the basement of the PCT. This work was funded by Ministry of Science and Technology (104-2811-M-002211). Thanks are due to Dr. Carla Dimalanta and Dr. Yumul and their lab students for providing help with the field work in the Philippines. The authors would like to thank HuangLin Chen who was a great help in field during sample collection and later helping in the lab with sample analyses. Thanks are extended to Prof. Sun-Lin Chung for providing the lab facility and Dr. Hao-Yang Lee for his assistance in the Hf analyses. Prof. Mei-Fei Chu and an anonymous reviewer are kindly acknowledged for very constructive reviews that helped us to clarify our work.

\section{REFERENCES}

Aurelio, M. A., M. T. Forbes, K. J. L. Taguibao, R. B. Savella, J. A. Bacud, D. Franke, M. Pubellier, D. Savva, F. Meresse, S. Steuer, and C. D. Carranza, 2014: Middle to Late Cenozoic tectonic events in south and central Palawan (Philippines) and their implications to the evolution of the south-eastern margin of South China Sea: Evidence from onshore structural and offshore seismic data. Mar. Petrol. Geol., 58, 658-673, doi: 10.1016/j.marpetgeo.2013.12.002. [Link]

Canto, A. P. B., J. T. Padrones, R. A. B. Concepcion, A. D. C. Perez, R. A. Tamayo, C. B. Dimalanta, D. V. Faustino Eslava, K. L. Queaño, and G. P. Yumul, 2012: Geology of northwestern Mindoro and its offshore islands: Implications for terrane accretion in west Central Philippines. J. Asian Earth Sci., 61, 78-87, doi: 10.1016/j.jseaes.2012.08.006. [Link]

Deng, K., S. Yang, C. Li, N. Su, L. Bi, Y.-P. Chang, and S.-C. Chang, 2017: Detrital zircon geochronology of river sands from Taiwan: Implications for sedimentary provenance of Taiwan and its source link with the east China mainland. Earth-Sci. Rev., 164, 31-47, doi: 10.1016/j.earscirev.2016.10.015. [Link]

Dimalanta, C. B., E. G. L. Ramos, G. P. Yumul, and H. Bellon, 2009: New features from the Romblon Island Group: Key to understanding the arc-continent collision in Central Philippines. Tectonophysics, 479, 120 129, doi: 10.1016/j.tecto.2009.02.015. [Link]

Faure, M. and K. Ishida, 1990: The Mid-Upper Jurassic olistostrome of the west Philippines: A distinctive key-marker for the North Palawan block. J. Southeast Asian Earth Sci., 4, 61-67, doi: 10.1016/07439547(90)90026-a. [Link]

Faure, M., Y. Marchadier, and C. Rangin, 1989: Pre-Eocene Synmetamorphic Structure in the Mindoro-RomblonPalawan Area, West Philippines, and implications for the history of southeast Asia. Tectonics, 8, 963-979, doi: 10.1029/tc008i005p00963. [Link]

Gabo, J. A. S., C. B. Dimalanta, M. G. S. Asio, K. L. Queaño, G. P. Yumul, and A. Imai, 2009: Geology and geochemistry of the clastic sequences from Northwestern Panay (Philippines): Implications for provenance and geotectonic setting. Tectonophysics, 479, 111-119, doi: 10.1016/j.tecto.2009.02.004. [Link]

Gervasio, F. C., 1967: Age and nature of orogenesis of the philippines. Tectonophysics, 4, 379-402, doi: 10.1016/0040-1951(67)90006-6. [Link]

Griffin, W. L., X. Wang, S. E. Jackson, N. J. Pearson, S. Y. O'Reilly, X. Xu, and X. Zhou, 2002: Zircon chemistry and magma mixing, SE China: In-situ analysis of $\mathrm{Hf}$ isotopes, Tonglu and Pingtan igneous complexes. Lithos, 61, 237-269, doi: 10.1016/s0024-4937(02)000828. [Link] 
Günther, D. and C. A. Heinrich, 1999: Enhanced sensitivity in laser ablation-ICP mass spectrometry using heliumargon mixtures as aerosol carrier. J. Anal. At. Spectrom., 14, 1363-1368, doi: 10.1039/a901648a. [Link]

Hamilton, W. B., 1979: Tectonics of the Indonesian Region, Professional Paper 1078, US Geological Survey, $345 \mathrm{pp}$.

Hashimoto, W. and T. Sato, 1973: Geological structure of North Palawan, and its bearing on the Geological History of the Philippines. In: Kobayashi, T. and R. Toriyama (Eds.), Geology and Paleontology of SE Asia, Vol. 13, 145-161.

He, M., H. Zheng, and P. D. Clift, 2013: Zircon U-Pb geochronology and Hf isotope data from the Yangtze River sands: Implications for major magmatic events and crustal evolution in Central China. Chem. Geol., 360361, 186-203, doi: 10.1016/j.chemgeo.2013.10.020. [Link]

Holloway, N. H., 1982: North Palawan Block, Philippines Its Relation to Asian Mainland and Role in Evolution of South China Sea. AAPG Bull., 66, 1355-1383, doi: 10.1306/03b5a7a5-16d1-11d7-8645000102c1865d. [Link]

Kiessling, W. and E. Flügel, 2000: Late paleozoic and Late Triassic limestones from north Palawan Block (Philippines): Microfacies and paleogeographical implications. Facies, 43, 39-77, doi: 10.1007/bf02536984. [Link]

Knittel, U., 2011: 83 Ma rhyolite from Mindoro - evidence for Late Yanshanian magmatism in the Palawan Continental Terrane (Philippines). Isl. Arc, 20, 138-146, doi: 10.1111/j.1440-1738.2010.00744.x. [Link]

Knittel, U. and U. Daniels, 1987: Sr-isotopic composition of marbles from the Puerto Galera area (Mindoro, Philippines): Additional evidence for a Paleozoic age of a metamorphic complex in the Philippine island arc. Geology, 15, 136-138, doi: 10.1130/0091-7613(1987) 15<136:SCOMFT $>2.0 . \mathrm{CO} ; 2$. [Link]

Knittel, U., C.-H. Hung, T. F. Yang, and Y. Iizuka, 2010: Permian arc magmatism in Mindoro, the Philippines: An early Indosinian event in the Palawan Continental Terrane. Tectonophysics, 493, 113-117, doi: 10.1016/j. tecto.2010.07.007. [Link]

Knittel, U., M. Walia, S. Suzuki, C. B. Dimalanta, R. Tamayo, T. F. Yang, and G. P. Yumul, 2017: Diverse protolith ages for the Mindoro and Romblon Metamorphics (Philippines): Evidence from single zircon U-Pb dating. Isl. Arc, 26, e12160, doi: 10.1111/iar.12160. [Link]

Lan, Q., Y. Yan, C.-Y. Huang, M. Santosh, Y.-H. Shan, W. Chen, M. Yu, and K. Qian, 2016: Topographic architecture and drainage reorganization in Southeast China: Zircon $\mathrm{U}-\mathrm{Pb}$ chronology and $\mathrm{Hf}$ isotope evidence from Taiwan. Gondwana Res., 36, 376-389, doi: 10.1016/j. gr.2015.07.008. [Link]
Li, X.-H., Z.-X. Li, W.-X. Li, and Y. Wang, 2006: Initiation of the Indosinian Orogeny in South China: Evidence for a Permian Magmatic Arc on Hainan Island. J. Geol., 114, 341-353, doi: 10.1086/501222. [Link]

Li, X.-H., Z.-X. Li, B. He, W.-X. Li, Q.-L. Li, Y. Gao, and X.-C. Wang, 2012a: The Early Permian active continental margin and crustal growth of the Cathaysia Block: In situ U-Pb, Lu-Hf and $\mathrm{O}$ isotope analyses of detrital zircons. Chem. Geol., 328, 195-207, doi: 10.1016/j.chemgeo.2011.10.027. [Link]

Li, X.-H., Z.-X. Li, and W.-X. Li, 2014: Detrital zircon $\mathrm{U}-\mathrm{Pb}$ age and $\mathrm{Hf}$ isotope constrains on the generation and reworking of Precambrian continental crust in the Cathaysia Block, South China: A synthesis. Gondwana Res., 25, 1202-1215, doi: 10.1016/j.gr.2014.01.003. [Link]

Li, Z.-X., X.-H. Li, S.-L. Chung, C.-H. Lo, X. Xu, and W.-X. Li, 2012b: Magmatic switch-on and switch-off along the South China continental margin since the Permian: Transition from an Andean-type to a Western Pacific-type plate boundary. Tectonophysics, 532-535, 271-290, doi: 10.1016/j.tecto.2012.02.011. [Link]

McCabe, R., J. Almasco, and W. Diegor, 1982: Geologic and paleomagnetic evidence for a possible Miocene collision in western Panay, central Philippines. Geology, 10, 325-329, doi: 10.1130/0091-7613(1982)10<3 25:GAPEFA $>2.0 . \mathrm{CO} ; 2$. [Link]

Scherer, E., C. Münker, and K. Mezger, 2001: Calibration of the Lutetium-Hafnium clock. Science, 293, 683-687, doi: 10.1126/science.1061372. [Link]

Suggate, S. M., M. A. Cottam, R. Hall, I. Sevastjanova, M. A. Forster, L. T. White, R. A. Armstrong, A. Carter, and E. Mojares, 2014: South China continental margin signature for sandstones and granites from Palawan, Philippines. Gondwana Res., 26, 699-718, doi: 10.1016/j.gr.2013.07.006. [Link]

Suzuki, S., S. Takemura, G. P. Yumul, S. D. David, and D. K. Asiedu, 2000: Composition and provenance of the Upper Cretaceous to Eocene sandstones in Central Palawan, Philippines: Constraints on the tectonic development of Palawan. Isl. Arc, 9, 611-626, doi: 10.1111/j.1440-1738.2000.00306.x. [Link]

Taylor, B. and D.E. Hayes, 1980: The Tectonic Evolution of the South China Basin. In: Hayes, D. E. (Ed.), The Tectonic and Geologic Evolution of Southeast Asian Seas and Islands, American Geophysical Union, Washington, D. C., 89-104, doi: 10.1029/GM023p0089. [Link]

Taylor, B. and D. E. Hayes, 1983: Origin and History of the South China Sea Basin. In: Hayes, D. E. (Ed.), The Tectonic and Geologic Evolution of Southeast Asian Seas and Islands: Part 2, American Geophysical Union, Washington, D. C., 23-56, doi: 10.1029/GM027p0023. [Link]

Tsutsumi, Y., K. Yokoyama, K. Terada, and Y. Sano, 2003: 
SHRIMP U-Pb dating of detrital zircons in metamorphic rocks from northern Kyushu, western Japan. $J$. Mineral. Petrological Sci., 98, 181-193, doi: 10.2465/ jmps.98.181. [Link]

Tsutsumi, Y., K. Yokoyama, K. Horie, K. Terada, and H. Hidaka, 2006: SHRIMP U-Pb dating of detrital zircons in paragneiss from Oki-Dogo Island, western Japan. $J$. Mineral.Petrological Sci., 101, 289-298, doi: 10.2465/ jmps.060127. [Link]

Van Hattum, M. W., R. Hall, A. L. Pickard, and G. J. Nichols, 2006: Southeast Asian sediments not from Asia: Provenance and geochronology of north Borneo sandstones. Geology, 34, 589-592, doi: 10.1130/g21939.1. [Link]

Walia, M., U. Knittel, S. Suzuki, S. L. Chung, R. E. Pena, and T. F. Yang, 2012: No Paleozoic metamorphics in Palawan (the Philippines)? Evidence from single grain U-Pb dating of detrital zircons. J. Asian Earth Sci., 52, 134-145, doi: 10.1016/j.jseaes.2012.03.005. [Link]

Walia, M., T. F. Yang, U. Knittel, T.-K. Liu, C.-H. Lo, S.-L. Chung, L. S. Teng, C. B. Dimalanta, G. P. Yumul, and W. M. Yuan, 2013: Cenozoic tectonics in the Buruanga Peninsula, Panay Island, Central Philippines, as constrained by $\mathrm{U}-\mathrm{Pb},{ }^{40} \mathrm{Ar} /{ }^{39} \mathrm{Ar}$ and fission track thermochronometers. Tectonophysics, 582, 205-220, doi: 10.1016/j.tecto.2012.10.002. [Link]

Wang, Y., W. Fan, G. Zhao, S. Ji, and T. Peng, 2007: Zircon $\mathrm{U}-\mathrm{Pb}$ geochronology of gneissic rocks in the Yunkai massif and its implications on the Caledonian event in the South China Block. Gondwana Res., 12, 404-416, doi: 10.1016/j.gr.2006.10.003. [Link]

Wolfart, R., P. Čepek, F. Gramann, E. Kemper, and H. Porth, 1986: Stratigraphy of Palawan Island, Philippines. Newsletters on Stratigraphy, 16, 19-48, doi: 10.1127/nos/16/1986/19. [Link]

Woodhead, J. D. and J. M. Hergt, 2005: A preliminary appraisal of seven natural zircon reference materials for in situ Hf isotope determination. Geostand. Geoanal. Res., 29, 183-195, doi: 10.1111/j.1751-908x.2005. tb00891.x. [Link]

Wu, F. Y., Y. H. Yang, L. W. Xie, J. H. Yang, and P. $\mathrm{Xu}$, 2006: Hf isotopic compositions of the standard zircons and baddeleyites used in U-Pb geochronol- ogy. Chem. Geol., 234, 105-126, doi: 10.1016/j.chemgeo.2006.05.003. [Link]

Xu, X., S. Y. O'Reilly, W. L. Griffin, X. Wang, N. J. Pearson, and Z.He, 2007: The crust of Cathaysia: Age, assembly and reworking of two terranes. Precambrian Res., 158, 51-78, doi: 10.1016/j.precamres.2007.04.010. [Link]

Xu, Y., Q. Sun, L. Yi, X. Yin, A. Wang, Y. Li, and J. Chen, 2014: Detrital zircons U-Pb age and Hf isotope from the western side of the Taiwan Strait: Implications for sediment provenance and crustal evolution of the northeast Cathaysia Block. Terr. Atmos. Ocean. Sci., 25, 505-535, doi: 10.3319/TAO.2014.02.18.01(TT). [Link]

Xu, Y., C. Y. Wang, and T. Zhao, 2016: Using detrital zircons from river sands to constrain major tectonothermal events of the Cathaysia Block, SE China. J. Asian Earth Sci., 124, 1-13, doi: 10.1016/j.jseaes.2016.04.012. [Link]

Yu, J.-H., L. Wang, S. Y. O’Reilly, W. L. Griffin, M. Zhang, C. Li, and L. Shu, 2009: A Paleoproterozoic orogeny recorded in a long-lived cratonic remnant (Wuyishan terrane), eastern Cathaysia Block, China. Precambrian Res., 174, 347-363, doi: 10.1016/j.precamres.2009.08.009. [Link]

Yu, J.-H., S. Y. O’Reilly, L. Wang, W. L. Griffin, M. F. Zhou, M. Zhang, and L. Shu, 2010: Components and episodic growth of Precambrian crust in the Cathaysia Block, South China: Evidence from U-Pb ages and Hf isotopes of zircons in Neoproterozoic sediments. Precambrian Res., 181, 97-114, doi: 10.1016/j.precamres.2010.05.016. [Link]

Yumul, G. P., C. B. Dimalanta, and R. A. Tamayo, 2005: Indenter-tectonics in the Philippines: Example from the Palawan Microcontinental Block - Philippine Mobile Belt Collision. Resour. Geol., 55, 189-198, doi: 10.1111/j.1751-3928.2005.tb00240.x. [Link]

Zamoras, L. R., M. G. A. Montes, K. L. Queaño, E. J. Marquez, C. B. Dimalanta, J. A. S. Gabo, and G. P. Yumul, 2008: Buruanga peninsula and Antique Range: Two contrasting terranes in Northwest Panay, Philippines featuring an arc-continent collision zone. Isl. Arc, 17, 443-457, doi: 10.1111/j.1440-1738.2008.00645.x. [Link] 